\title{
New Syndrome: Partially Ectodermal Growth Deficiency (Fidan Syndrome)
}

\author{
Vural Fidan* \\ Otorhinolaryngology Department, Yunus Emre Government Hospital, Turkey
}

\begin{abstract} but there is not any case that has papillomatas on tonsils. ntellectual disability, curly hair and papillomatas on interdental space . diagnosis.

\section{Introduction}

Ectoderm is one of the three primitive embryo layers. The ectodermal dysplasias consist a great, heterogeneous disorders which are described as primary defects in the growth of 2 or more tissues of ectoderm. The most involved tissues are the teeth, skin and its appendages. From Thurnam who was reported the first ectodermal dysplasia patient in 1848, more than 192 different disorders have been defined [1].
\end{abstract}

Background: Ectoderm is a primary germ layer. The ectodermal dysplasias are defined as developmental defects of embryonic ectoderm. Different types were defined

Case presentation: Herein, we report two girls, one was 5-year-old and the second was fifty-five year-old diagnosed with tonsillary papillomatas. Also both have

Conclusion: Multidisciplinary approach to syndromic patients is always needed. Physicians must be carefull about signs and symptoms of these patients for suitable

Here in, we reported first cases whom have tonsillary papillomatozis, papillomata on interdental space, curly hair and mental retardation.

\section{Case Report}

Two girls, presented to otorhinolaryngology department of Yunus Emre Goverment Hospital (Figures 1 and 2). Antenatal, natal and neonatal histories were noncontributory. There was intellectual disability in all subjects. They have papillomata on tonsils and curly hair. Also they have discrete tooth and papillomata on maxillary interdental space. Both cardiologist, orthopedist and paediatrician opinions were normal.

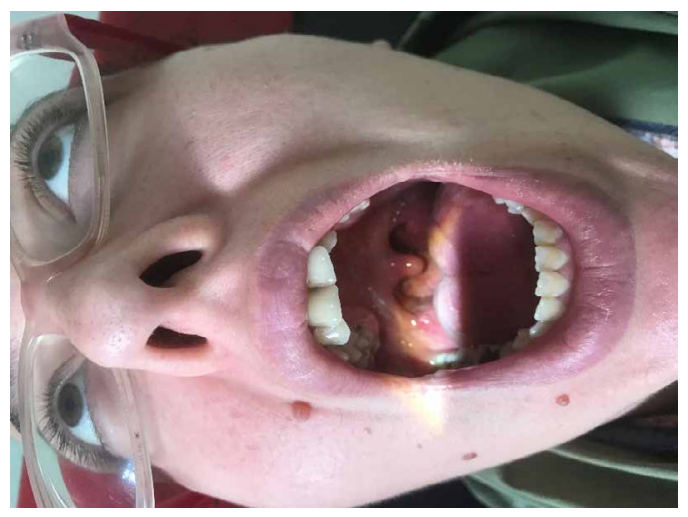

Figure 1. Fity-five year old girl's mouth

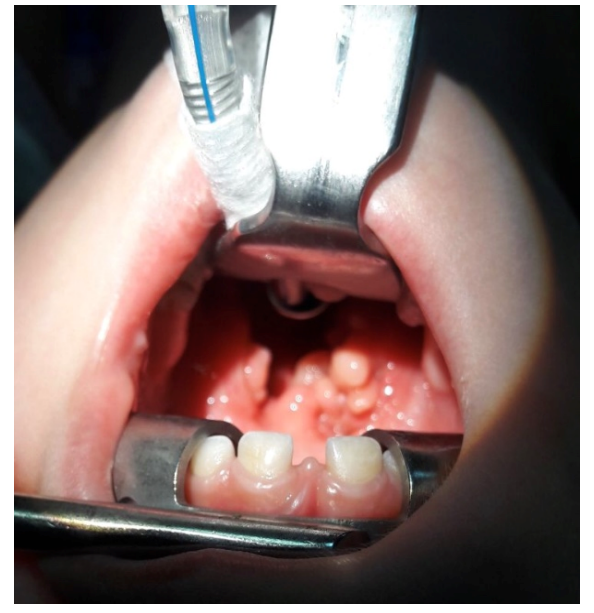

Figure 2. Five year old girl's mouth

\section{Discussion}

Ectodermal dysplasia syndromes are uncommon disorders. Although, antenatal diagnosis can be made by detailed ultrasound, clinical diagnosis is more certain after birth [2].

The first classification system of the ectodermal dysplasias was defined by Freire-Maia and Pinheiro in 1982 [1,3]. Present classification of ectodermal dysplasias is established on clinical findings [4].

${ }^{\star}$ Correspondence to: Vural Fidan, Otorhinolaryngology Department, Yunus Emre Government Hospital, Eskisehir, Turkey, Tel: +90 505560 6842; E-mail: vuralf@mynet.com

Key words: ectoderm, growth deficiency, displasia, mental retardation

Received: January 15, 2019; Accepted: January 21, 2019; Published: January 25, 2019 
The most impressing clinical charasteristic is chondrodysplasia that disturbs the ossification of bones [5]. But in our patients there were no orthopaedic problems.

Congenital cardiac malformations are exhibit in about half of the ectodermal dysplasia subjects [3]. Also our patients do not have any cardiac problems. The oral appearances of ectodermal dysplasia contain upper lip fusion, accessory frenula, ankyloglossia, microdontia teeth and supernumerary teeth [6]. In our patients, there was papillomata on tonsils and maxillary interdental space.

Also, urogenital abnormalities are present in about quater of the cases [1]. Infrequently, hematopoietic disorders are found. There were not any of these findings in our subjects.

Intellectual disability was present in both two cases. In conclusion, a multidisciplinary approach is always needed. These include orthopaedic surgeon, otorhinolaryngologist, dentist and paediatrician for suitable diagnosis, management and rehabilitation of such patients. Syndromic patients must be assessed closely and physicians must be carefull about signs and symptoms.

Note: These cases will be presented in 4th Spring Congress Of Otorhinolaryngology in Antalya.

\section{References}

1. Pinheiro M, Freire-Maia N (1994) Ectodermal dysplasias: a clinical classification and a causal review. Am J Med Genet 2: 153-62. [Crossref]

2. Gopal G, Belavadi GB (2014) Case report of a child with EllisVancreveld syndrome Int J Pharm Biomed Res 5: 14-7.

3. Lamartine J (2003) Towards a new classification of ectodermal dysplasias. Clin Exp Dermatol 28: 351-55. [Crossref]

4. Hegde K, Puthran RM, Nair G, Nair PP (2011) Ellis-Van Creveld syndromeea report of two siblings. BMJ Case Rep 1-8. [Crossref]

5. Koyuncuoglu CZ, Metin S, Saylan I, Calisir K, Tuncer O, et al. (2014) Full-mouth rehabilitation of a patient with ectodermal dysplasia with dental implants. J Oral Implantol 6: 714-21. [Crossref]

6. Pinheiro M, Freire-Maia N (1994) Ectodermal dysplasias: a clinical classification and a causal review. Am J Med Genet 2: 153-62. [Crossref]

Copyright: (C2019 Fidan V. This is an open-access article distributed under the terms of the Creative Commons Attribution License, which permits unrestricted use, distribution, and reproduction in any medium, provided the original author and source are credited. 